\title{
Moderating Effect of Political Risk on the Relationship between Capital Expenditure and Sectoral Economic Growth in Kenya
}

\author{
Brenda Molonko ${ }^{1} \&$ Samuel Nathaniel Ampah ${ }^{2}$ \\ ${ }^{1}$ Finance Officer, State Department for Natural Resources, Nairobi, Kenya \\ ${ }^{2}$ Finance Manager, Africa Cluster, S.C. Johnson of South Africa (Pty), Limited, Johannesburg, South Africa \\ Correspondence: Brenda Molonko, Finance Officer, State Department for Natural Resources, Nairobi, Kenya. \\ Tel: 254-721-948-684. E-mail: bmolonko@gmail.com
}

Received: November 8, 2017

Accepted: December 5, 2017

Online Published: December 10, 2017

doi:10.5539/ijef.v10n1p129

URL: https://doi.org/10.5539/ijef.v10n1p129

\begin{abstract}
The study sought to determine the effect of capital expenditure on Sectoral economic growth and the moderating effect of political risk on the relationship using Auto Regressive Distributed Lag model. The study targeted 11 sectors that receive government expenditure and adopted positivist philosophy and a causal research design. Secondary data for the period 2006-2015 was collected from Kenya National Bureau of Statistics Statistical Abstracts, Kenya National Audit Office reports and Political Risk Group reports. The study conducted Hausman Test, Panel Stationarity Test and Heterogeneity Test as preliminary tests. The study found that capital expenditure has a significant effect on Sectoral economic growth both in the long run and short run. The study further found that political risk has a significant moderating effect on the relationship between capital expenditure and Sectoral economic growth in the long run at the significance level of 0.05 . The study concluded that capital expenditure has an effect on sectoral economic growth in Kenya both instantaneously and in the long run. As well, Political risk curbs the effect of capital expenditure in the long run. The study recommends enhancement of capital expenditure. Additionally, the government should enhance political stability to accelerate growth.
\end{abstract}

Keywords: political risk, sectoral economic growth, capital expenditure

\section{Background to the Study}

The effect of government expenditure on GDP growth has generated a series of debates among scholars (Alshahrani \& Alsadiq, 2014; Srinivasan, 2013; Odhiambo, 2013; Gangal \& Gupta, 2013; Njuguna, 2009). For instance, some scholars such as Ekpung, (2014), Cooray (2009) and Ranjan and Sharma (2008) largely claim that increase in government expenditure on socio-economic and infrastructures promotes economic growth. On the other hand, other scholars such as Ojwang (2013) and Olopade and Olopade (2010) argue on the platform that increase in government spending does not promote growth and development but rather reduces the overall performance of the economy as increase in government spending may result from an increase in taxes or borrowing (Taiwo \& Agbatogun, 2011). It is against the backdrop of such differing scholarly opinions that empirical and theoretical studies have continued to explore the question of whether the raising of government expenditure has positive or negative effects on GDP.

The Sectoral growth trends in Indian economy have been encouraging for investors with the main contributors to the overall rise of the different Sectoral trends being manufacturing and service Sectors. Electricity, gas and water supply performed well and recorded an impressive growth rate of $8.3 \%$. Trade, hotels, transport and communication registered a growth rate of $12 \%$. The growth rate of agriculture, forestry \& fishing and mining \& quarrying were estimated at $3.8 \%$, and $3.2 \%$ respectively during the $1^{\text {st }}$ quarter of the year 2007 and 2008 . Trade, hotels, transport, and communication registered a growth rate of $12 \%$ (Statistics Times, 2015). In Russia, the services Sector, that is, trade, transport and communications, government, financial and business services and personal, social, and community services grew from $39 \%$ in 1990 to $69.1 \%$ in the year 2015 . Agriculture and industry on the other hand averaged $1.5 \%$ and $29.4 \%$ respectively. Australia, United Kingdom, and the USA has the least growth in Agriculture and higher growth rates in Service Sectors (World Bank, 2015a).

According to Kumo, Riel and Omilola (2014), labor unrest continued to affect performance in the manufacturing, mining and agricultural Sectors in South Africa. Mining Sector expanded for the first time since the year 2011 
posting $2.5 \%$ annual growth as iron ore and coal production largely. Agricultural Sector experienced violent strikes early in 2013 causing growth to collapse from $4 \%$ in the year 2012 to $1.4 \%$ in the year 2013. Services, which account for $25 \%$ of the South African economy rose to 2.6\% in the year 2013 compared to 5\% in the year 2012. In the East Africa region, Rwanda's economic growth has been fluctuating across all the Sectors with the highest average aggregate GDP of $8.1 \%$ in the period 2000-2010 (Rutayisire, 2013). In the same way, Tanzania's economy has been growing with agriculture and infrastructure Sectors contributing more to the GDP compared to health and education Sectors (World Bank, 2011).

Sectoral economic growth in Kenya has been hampered by hefty dependence on a few agricultural imports, population growth, prolonged drought, power rationing, abating infrastructure, extreme disparities of wealth, terrorism, poor governance \& corruption and post-election violence (World Bank, 2014). Even with these challenges, World Bank views Kenya as one of the fastest-growing economies in East Africa, with a GDP growth rate forecast of 6.0\% in the year 2015 and 6.6\% in the year 2016. In September 2014, Kenya changed the base calculation year for measuring its GDP to the year 2009 from the year 2001, and this catapulted it to number nine in the ranking of Africa's top 10 economies by GDP (World Bank, 2015c).

Agriculture and Forestry Sector experienced a negative growth rate of $-4.98 \%$ and $-2.30 \%$ in the years 2007,2008 and 2009 respectively and the highest positive growth of 5.62\% in 2015. The decline could be attributed to adverse weather conditions, year 2007/2008 post-election violence and decreased international horticulture demand in 2009 ( Republic of Kenya, 2010). Education Sector recorded the highest growth of $11.7 \%$ in the year 2012 and $0.9 \%$, being the lowest, in the year 2006. The low growth of Education Sector could be attributed to the donor funding that declined in the year 2008 and the year 2009 because of reduced commitment owing to mismanagement of free primary education funds. The effect was a drop in GDP from 9.2\% in the year 2008 to 5.3\% in the year 2009 then later on stabilized at an average of 8.81\% in the year 2011, 2012 and 2013 when donor commitments to education Sector continued after the government took bold steps to prosecute corrupt officials (Republic of Kenya, 2013).

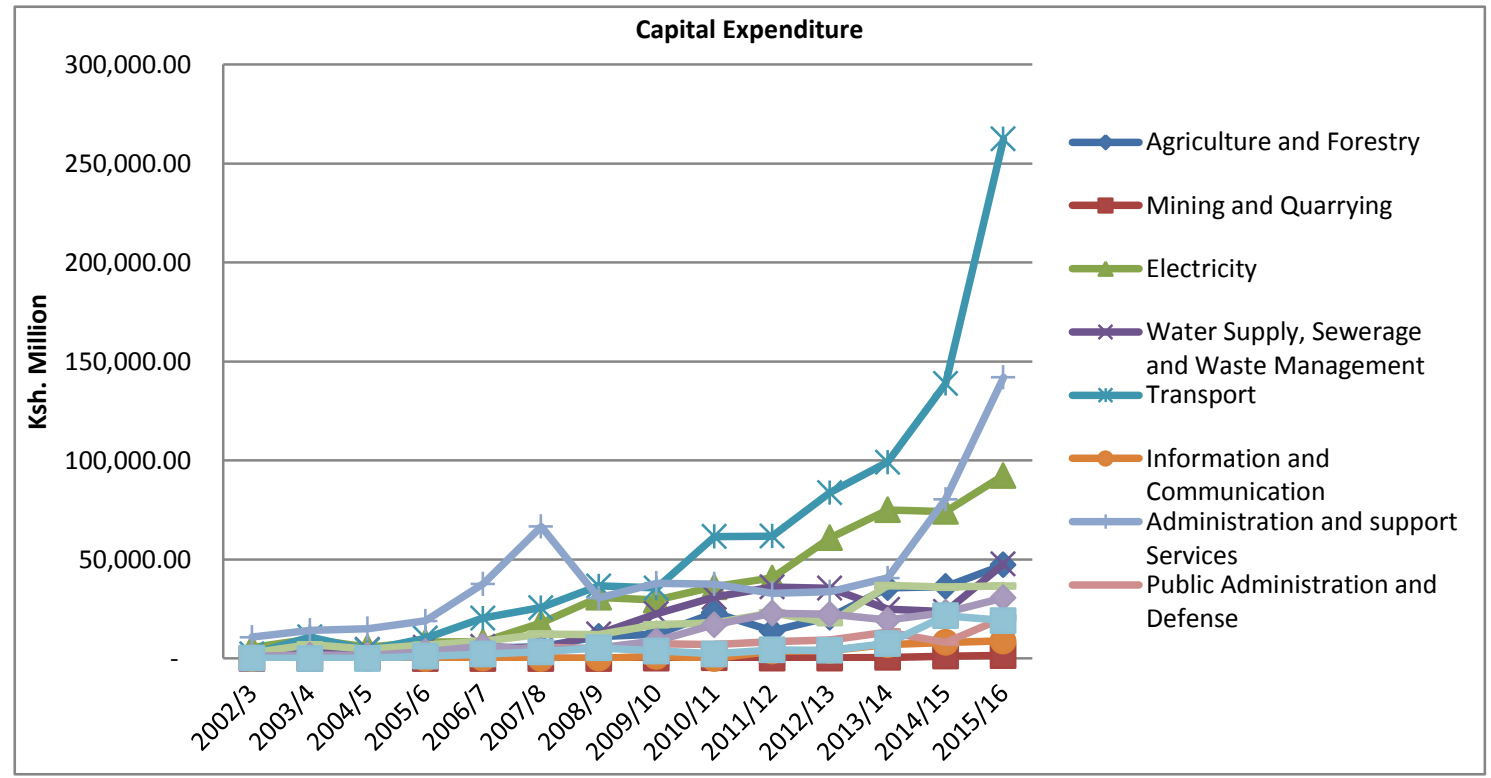

Figure 1. Capital expenditure

Source: Various KNBS Statistical Abstracts, Kenya National Audit Reports (2003 - 2016) and Printed Estimates Financial Year 2015/16.

The government increased capital expenditure to Education, Transport and Communication, Electricity and Water supply Sectors from the years 1992 to 2012. In 1992, expenditure on Transport and Communication, Electricity and Water supply went down because money was diverted to finance the 1992 general elections. In addition, infrastructure Sector, which ordinarily attracts much donor funds, went down, attributed to low donor confidence leaving the government with little to spend in this crucial Sector (Muthui, Maingi, Gideon, Thuku, \& Kosimbei, 2013). The National Rainbow Coalition (NARC) government upon taking office was passionate with capital projects and increasingly allocated money to Transport and Communication, Electricity and Water supply Sectors for expansion of roads networks, water services, energy projects, telecommunication projects, health, 
education and rehabilitation of airports (UNDP, 2012).

Capital expenditure on Transport, Electricity, Administration and Support Services, Agriculture and Forestry Sectors has been on upward trajectory from the financial year 2002/3 to 2015/16. This is because it finances the Vision 2030 flagship projects that include expansion of road networks, power generation that targets additional 5,000 Megawatts by the year 2017, increasing access to electricity with a target of 70\% accessibility by the year 2020 , expansion of irrigation projects with an annual target of $40,000 \mathrm{Ha}$, construction of Standard Gauge Railway, expansion and modernization of airports and seaports among others (Republic of Kenya, 2007; Republic of Kenya, 2015a).

Public Administration and Defense, Education and Health Sectors expenditure has a relatively smaller share of capital expenditure since most of their activities are recurrent in nature. Administration and Support Services utilize their capital expenditure on Public Financial Management, overall policy direction, management of public affairs, economic policy and national planning, devolution services, Arid and Semi-Arid lands development and special programs like rehabilitation of National Youth Service (Republic of Kenya, 2015b). Arts, Culture and Recreation Sector utilizes its expenditure on promotion and development of sports, culture and film and music industry (Republic of Kenya, 2014).

\section{Statement of the Problem}

Government of Kenya is currently implementing the Second Medium Term Plan of Vision 2030. Growth objectives underpinning the Vision 2030 require the rate of growth of the economy to have risen from $6.1 \%$ achieved in 2006 to $10 \%$ in the years 2012 and 2013, and to sustain that growth (Republic of Kenya, 2007b). However, the annual GDP growth in the year 2012, 2013, 2015 and 2016 was 4.5\%, 5.7\%, 5.7\% and 6.0\% respectively (Republic of Kenya, 2013c).

From the foregoing background literature, it is evident that the government of Kenya allocates substantial amounts of money to Agriculture and Forestry, Electricity and Water Supply, Education, Health Care, Economic Services, National Security, Defense and General Administration for implementation of Vision 2030 flagship projects that would contribute to $10 \%$ growth (Republic of Kenya, 2015a). However, despite the increase in capital expenditure on the mentioned Sectors, Sectoral economic growth has been fluctuating. For instance, capital expenditure to Agriculture and Forestry Sector has been on upward trajectory from the year 2006 to 2015 but the resultant allied GDP values fluctuated between $-5.0 \%, 10.0 \%$ and 5.6\% for the years 2008, 2010, and 2015 respectively. This was against the general proposition that when there is an increase in government expenditure in these Sectors, it is expected that the economy will exhibit positive economic growth (Abdinasir, 2013, Muthui et al., 2013) thus leaving it unclear capital expenditure significantly influences Sectoral economic growth especially in a developing economy such as Kenya. Government expenditure has also been restructured to enhance economic growth by increasing capital expenditures, especially those targeting public investments, such as education and health (Wanjiku, 2013). However, despite the reforms, economic growth has not kept pace with expenditure growth (Maingi, 2010).

Majority of the studies undertaken in Kenya focused on the general economy and aggregate expenditure and therefore scanty documented analysis of capital expenditure and sectoral economic growth in Kenya is avaliable. This study, therefore, sought to bridge knowledge gaps by attending to gaps documented in the foregoing, thereby, determining the effect of capital expenditure on Sectoral economic growth with political risk as a moderator in the relationship.

\section{Objectives of the Study}

i. To establish the effect of capital expenditure and Sectoral economic growth in Kenya.

ii. To establish the moderating effect of political risk on the relationship between capital expenditure and Sectoral economic growth in Kenya.

\section{Theoretical Review}

The theories that have been found to explain the effect of capital expenditure on Sectoral economic growth include Agency theory, Budget theory, Stewardship theory as well as Neo-Classical theory of growth. These theories were relevant to the study as highlighted below:

\section{1) Budget Theory by Key (1940)}

Valdimer Orlando Key is credited to have put the theory forward in 1940 after he recognized the need to have a budget theory in Public Finance. Key (1940) as cited in Khan and Hildreth (2002) tried to address the issue of Public Budgeting not having a theory by offering a solution that increases the allocative efficiency of 
government. Budget theory provides a perspective of looking at budgets as portfolios. The argument is that budget requests in the state are very similar to portfolios the finance managers in the private sector deal with on regular basis. The acceptance of these portfolios depends on their efficiency. The theory suggests that government managers would select portfolios that will maximize their utility subject to risk-return combination (Khan, 2002). Every year, the budget managers receive funding requests of activities from MDAs that exceed available resources. It is, therefore, possible to organize these activities into different combinations called portfolios. This notion of budgeting as a decision-making exercise involving multiple packages is consistent with portfolio theory developed by Harry Markowitz in 1950s (Marnix, 2004).

This theory adopts the notion of expected returns, variance co-variance and dominance in allocating funds (Cochrane, 2007). For example, the expected return on expenditure on education Sector would be the greatest number of children that can receive an education. Expected return can be formally defined as the expected return of a portfolio as the weighted average of the expected return of activities it contains. Dominance is a situation where one or more activities in a portfolio dominate others and a decision maker will most likely prefer some activities more than others (Khan, 2002).

Therefore the funds allocated for different activities in a portfolio must reflect the variance as much as possible for those activities. The efficient portfolio will be a combination that would maximize the expected return and minimize the variance (Cochrane, 2007). This theory has limitations that is the application of the theory to all activities, including those that are not divisible and how to deal with a situation when the number of activities facing a budget manager becomes very large (Rubin, 2007). It is possible to allocate resources efficiently to activities during the MTEF process in Kenya so as to maximize expected returns (Martin, 1997).

\section{2) Neo-Classical Theory of Growth by Solow-Swan (1956)}

This theory was advanced by Solow-Swan in 1956 as an exogenous growth model (Solow-Swan, 1956). It is an economic model of long-run economic growth set within the framework of neoclassical economics. It endeavors to explain long-run economic growth by looking at capital accumulation, labor or population growth, and increases in productivity. Productivity is enhanced by financing or supplying directly the investments that the private Sector would not supply in sufficient quantities due to various market failures like infrastructure projects and basic education and health expenditure, which could directly enhance private Sector productivity; efficient supply of some basic public services that are crucial to provide basic conditions for entrepreneur activity and long-term investment; and financing its own activities in the manner that minimizes distortions to private Sector savings and investment decision and to economic activities more generally (Romer, 1996).

It is on this basis that government expenditure can impact growth by affecting capital and/or labor as well as the generation and/or assimilation of technological progress reflected in total factor productivity (Maingi, 2010). Conversely, since the model assumes that the long-run growth rate is compelled by the population growth and the rate of technical progress, which is viewed to be exogenous, the effect of government expenditure on growth through production factors is considered to be only transitional (Dominick, 2002). The theory is applicable in Kenya in that Sectoral productivity is likely to increase if labor and capital are allocated with sufficient resources. Capital formation and government investment is captured under capital expenditure.

\section{Empirical Literature Review}

Nurudeen and Usman (2010) employed a disaggregated analysis using Johansen cointegration and Error Correction Model (ECM) to examine government expenditure and economic growth in Nigeria. The study established that total capital expenditure and government expenditure on education have a negative relationship with economic growth. In contrast, growing government expenditure on transport \& communication and health led to an increase in economic growth. Nurudeen and Usman (2010) excluded the effect political risk in their study. Besides that, key Sectors like agriculture and forestry Sector were excluded. The study by Nurudeen and Usman (2010) used aggregate GDP as opposed to Sectoral GDP.

Onokaya (2013) adopted a three-stage least squares (SLS) technique and macro-econometric model of simultaneous equations to capture the disaggregated impact of public capital expenditure on different Sectors of the economy. These Sectors are Agriculture, oil, infrastructure, service and manufacturing. Three-SLS is an estimator, which by its design takes care of any probable occurrence of non-stationarity and consequential possibility of spurious regressions was employed. Augmented Dickey Fuller (ADF) or Phillips-Perron (PP) tests were carried out to test for stationarity. The study found that public capital expenditure contributes positively to economic growth in Nigeria. The results of Onokaya (2013) study similarly indicate that public capital expenditure directly promotes the output of oil and infrastructure but is directly detrimental to the output of manufacturing and agriculture. The results suggest a positive but insignificant relationship to the services Sector. 
The results, however, confirm that public capital spending indirectly enhances economic growth by encouraging private Sector investments due to the facilitating role of government in the provision of public goods. The study, therefore, recommends the privatization of the state-owned enterprises and use of public-private-partnership arrangements to engender efficiency and effectiveness in public service delivery. This study did not go into details of service Sector that comprises of Sectors like education, health, and public administration, which has a component of capital expenditure.

Abdinasir (2013) using time series data covering the period 1980-2010 examined the relationship between public expenditure and economic growth in Kenya. Health, education, agriculture and infrastructure Sectors were selected for the study. The data was converted into log linear form. The Abdinasir (2013) study employed correlation research design and ECM to establish relationship dynamics. The Augmented Dickey- Fuller test (ADF) was carried out to ascertain the stationarity of time series data while cointegration test was used to test for a relationship between variables. The study established that expenditure to agriculture and infrastructure promotes economic growth while health and education were found to be negatively related to economic growth. The estimated model was a single regression equation with the growth rate of GDP as the dependent variable and expenditure to agriculture, education, health, and infrastructure as dependent variables. The Abdinasir (2013) findings from ECM model, however, indicated that there is no long-term relationship between variables. Abdinasir (2013) operationalized economic growth with aggregate GDP contrary to what this study is adopting. In addition, government expenditure was not disaggregated into current, capital and debt servicing. Besides, the moderating effect of political risk was not considered in the Abdinasir (2013) study.

Kosen and Muturi (2013) used log-linear form model to investigate the effect of Sectoral budgetary allocation on economic growth in Kenya. The model was used due to the sharpness in time series data in developing economics like Kenya. ADF test was carried out and found that all variables were non-stationary at levels leading to test for stationarity at the first difference that showed that all variables were stationary. Breush-Godfrey test for serial correlation was done, and this was preferred because of advantages over traditional techniques of cointegration. The study focused on health, defense, education, agriculture, manufacturing, transport and communication Sectors. The study established a long-run relationship between expenditure to agriculture and education and GDP. Health, defense, transport, and communication related positively but insignificantly. This is in contrast with Muthui et al. (2013), Abdinasir (2013) and Maingi (2010) who established a negative relationship between health, education, and economic growth. Kosen and Muturi (2013) did not split government expenditure into various components and functions namely current, capital and debt servicing. Further, economic growth was operationalized with aggregate GDP contrary to what this study is adopting. Kosen and Muturi (2013) assumed a direct relationship between variables (that is), absence of the moderating role of political risk was not captured.

Lagat (2015) studied foreign aid, government expenditure and Sectoral GDP growth in Kenya using a correlational research design with a focus on Education, Agriculture \& forestry and Health Sectors. The study utilized Panel Generalized Least Squares to estimate the effects of foreign aid and government expenditure on Sectoral GDP growth for the period 1980 to 2012. The empirical findings, showed that growth in public Sector wage employment, growth in non-public Sector wage employment and private investments have positive effects on Sectoral GDP growth while development expenditure was found to have negative effects on Sectoral GDP growth. Furthermore, the coefficients for the recurrent expenditure and foreign aid were found to be statistically insignificant whereas all the other variables' coefficients were statistically significant. Lagat (2015) however omitted other key Sectors in the economy hence difficult to generalize the findings to reflect the overall Sectoral growth in Kenya. Secondly, there have been several elections and political alignments from 1980 up to 2012 that affect the performance of Sectors yet the risks associated with political alignments are not captured in the study. Besides that, Lagat (2015) assumed a direct relationship between the independent and dependent variables that is the absence of moderating. Lastly, Lagat (2015) used printed estimates to capture capital expenditure, which do not reflect the actual audited government expenditures.

Majority of the studies reviewed focused on the general economy however capital expenditures are allocated to each Sector and therefore this study focused on Sectoral GDP growth that was omitted in the previous studies. Studies that focused on Sectoral economic growth in Kenya omitted key Sectors in the economy and used nominal values instead of real values. Besides that, the studies reviewed under the Kenyan context used total expenditure but this study focused on capital and as a component of government expenditure for each Sector. This provides a detailed analysis of capital expenditure in each Sector. From the literature, there is evidence that capital expenditure in some Sectors enhances growth while others hinder growth that could be as a result of other factors like political risk. This study, therefore, tested the moderating effect of political risk in the relationship 
between capital expenditure and Sectoral economic growth.

\section{Conceptual Framework}

Independent Variables

\author{
Capital Expenditure
}

Amount in Ksh.

\section{Dependent Variable}

Sectoral Economic Growth

Sectoral GDP growth (\% at

constant prices)

Source: Researcher (2015).

\section{Research Methodology}

Given the nature of the study problem herein, it was suggested that this study takes a positivist philosophy. A causal research design was adopted this study. This is because this design has historically been used to measure the effect a specific change has on existing norms and assumptions (Trochim, 2006). The study chose a target population of 11 Sectors that receive government expenditure. These Sectors are: Agriculture and Forestry, Mining and Quarrying, Electricity, Water Supply, Sewerage and Waste Management, Transport, Information and Communication, Public Administration and Defense, Education, Health, Administration \& Support Services and Arts, Culture \& Recreation Sectors. This study employed an Autoregressive Distributed Lag (ARDL) model developed by Pesaran et al. (2009) due to the following merits. Unlike Westerlund (2007), ARDL model is consistent even if there is a mixture of $\mathrm{I}(0)$ and $\mathrm{I}(1)$. It is concise in the sense that, it estimates the functional Error Correction Model (ECM) and tests for cointegration at the same time. To choose an efficient estimator among the three possible estimators (MG, PMG and DFE) of the Pesaran et al. (2009) for models 3.2 through 3.8, Hausman test was used. Panel Stationarity, Hausman test and Hetregoniety test to check whether sectors are unique were conducted before applying the ARDL Model.

\section{The model}

where

$$
\ln S G_{i t}=\beta_{0}+\beta_{1} \ln K E_{i t}+\mu_{i}+u_{i t}
$$

$\mathrm{SG}=$ Sectoral economic Growth

$\ln =$ The natural logarithms operator

$\mu_{i}=$ Individual Sectoral effect

$u_{i t}=$ Is idiosyncratic error term

$\beta_{0}=$ Is a constant

$\beta_{i}$ 's =Are coefficients for period representing lags for the current and previous year $\left(\mathrm{t}_{\mathrm{t}}\right.$ and $\left.\mathrm{t}-1\right)$

$\mathrm{KE}=$ Capital expenditure

PR=Political Risk

Introducing Political Risk as a variable

$$
\ln S G_{i t}=\beta_{0}+\beta_{1} \ln K E_{i t}+\beta_{2} \ln P R_{t}+\mu_{i}+u_{i t}
$$

Where $P R_{t}$ is Political Risk in year $t$

Political Risk as a moderator

$$
\ln S G_{i t}=\beta_{0}+\beta_{1} \ln K E_{i t}+\beta_{2} \ln P R_{t}+\beta_{3} \ln P R_{t} * \ln C E_{i t}+\mu_{i}+u_{i t}
$$


Table 1. Moderation decision making criteria

\begin{tabular}{llll}
\hline Scenario & Model 3.2 & Model 3.3 & Conclusion \\
\hline One & $\beta_{2}$ is significant & $\beta_{3}$ is insignificant & Moderating variable is an explanatory variable \\
\hline Two & $\beta_{2}$ is insignificant & $\beta_{3}$ are significant & Moderating variable has a moderating effect \\
\hline
\end{tabular}

Source: Whisman and McClelland (2005).

Table 1 above illustrates the two possible scenarios that can occur when political risk is introduced as a variable as well as a moderator. If scenario one occurs, then political risk is an explanatory variable rather than a moderator. If scenario two occurs, then Political risk is a moderator.

\section{Results, Findings and Discussion}

The specific objective was to establish the moderating effect of political risk on the relationship between capital expenditure and Sectoral economic growth in Kenya. Table 2 below presents the results of the test of hypothesis.

Table 2. Effect of capital expenditure on sectorial growth

\begin{tabular}{|c|c|c|c|c|c|c|}
\hline \multirow[b]{2}{*}{ Variables } & \multicolumn{2}{|c|}{ PMG } & \multicolumn{2}{|c|}{ MG } & \multicolumn{2}{|c|}{ DFE } \\
\hline & Long Run & Short Run & Long Run & Short Run & Long Run & Short Run \\
\hline \multirow[t]{2}{*}{ Capital Expenditure } & $0.0290 * *$ & $0.0627 * * *$ & $0.0686^{* * * *}$ & 0.00572 & $0.131 * * *$ & -0.0212 \\
\hline & $(0.0138)$ & $(0.0215)$ & $(0.0248)$ & $(0.0324)$ & $(0.00625)$ & $(0.0151)$ \\
\hline \multirow[t]{2}{*}{ Constant } & & $0.934 * * *$ & & $13.46 * * *$ & & $21.14 * * *$ \\
\hline & & $(0.324)$ & & $(4.557)$ & & $(2.533)$ \\
\hline \multicolumn{7}{|c|}{ SPEED OF ADJUSTMENT } \\
\hline & & $-0.307 * * *$ & & $-0.984 * * *$ & & $-1.189 * * *$ \\
\hline & & $(0.0951)$ & & $(0.167)$ & & $(0.102)$ \\
\hline
\end{tabular}

Note. Standard errors in parentheses. $* * * \mathrm{p}<0.01, * * \mathrm{p}<0.05, * \mathrm{p}<0.1$.

\section{$\mathrm{Ho}_{1}$ : Capital Expenditure has no significant effect on Sectoral Economic Growth in Kenya.}

In view of the first objective, the study sought to determine the effect of capital expenditure on Sectoral economic growth in Kenya. The null hypothesis $\left(\mathrm{H}_{1}\right)$ that is; capital expenditure has no effect on Sectoral growth in Kenya was tested. The efficient PMG estimates in Table 2 show that the coefficient of capital expenditures in the short run is 0.0627 with a corresponding p-value less than 0.01 and t statistic of 2.92 that is, $(0.0627 / 0.0215)=2.92$. Therefore, the null hypothesis that capital expenditure has no effect on Sectoral economic growth in Kenya is rejected. Since Sectoral growth and capital expenditures enter model 3.1 in log form the coefficient has elasticity. The magnitude of the coefficient shows that other things being equal and with a one per cent increase in capital spending in the short run, Sectoral growth increases by 6.27 percentage points.

In addition, Table 2 above indicates that the coefficient of capital expenditures in the long run is 0.0290 with a corresponding p-value less than 0.05 and $t$ statistic of 2.10 that is, $(0.0290 / 0.0138)=2.10$. The null hypothesis is therefore not supported at a significance level of 0.05. Since Sectoral growth and capital expenditures enter model 3.1 in $\log$ form the coefficient has elasticity. The magnitude of the coefficient shows that other things being equal and with a one per cent increase in capital spending in the long run Sectoral growth increases by 2.9 percentage points. Hence, the null hypothesis that capital expenditure has no effect on Sectoral economic growth is rejected.

This is in contrast with Lagat (2015) who established a negative relationship between capital expenditure and Sectoral GDP growth. Ogundipe and Oluwatobi (2010) established a positive relationship between capital expenditure and economic growth in the long run. Nurudeen and Usman (2010) established mixed results on the effect of capital expenditure and economic growth with education being negative and other Sectors being positive. Capital expenditure financing robust infrastructure reduces cost of doing business like cheaper electricity and water bills, reduced amounts spent on vehicle repairs and it saves time and fuel lost in traffic jam snarl-ups and unwarranted delays (Muthui et al., 2013). Capital expenditure on Agriculture increase productivity on agriculture Sector which is the largest contributor to the GDP and reduces food insecurity.

$\mathrm{HO}_{2}$ : Political Risk has no significant moderating effect on the relationship between government Expenditure and Sectoral Economic Growth in Kenya.

The moderating effect of political risk under hypothesis two was estimated using models 3.2 and 3.3. Table 3 
below illustrates the estimates of model 3.2 and coefficient of interest as per model 3.2 is that of political risk. On the other hand, Table 3 reports the estimates of model 3.3.

Table 3. Political risk as a variable

\begin{tabular}{|c|c|c|c|c|c|c|}
\hline \multirow[b]{2}{*}{ VARIABLES } & \multicolumn{2}{|c|}{ PMG } & \multicolumn{2}{|c|}{ MG } & \multicolumn{2}{|c|}{ DFE } \\
\hline & Long Run & Short Run & Long Run & Short Run & Long Run & Short Run \\
\hline \multirow[t]{2}{*}{ Capital Expenditure } & -0.0136 & 0.0343 & 0.227 & 0.0258 & -0.0250 & $0.0737 * * *$ \\
\hline & $(0.0181)$ & $(0.0445)$ & $(0.231)$ & $(0.0323)$ & $(0.0341)$ & $(0.0229)$ \\
\hline \multirow[t]{2}{*}{ Political Risk } & 0.794 & 2.201 & -10.77 & 2.339 & -1.102 & 1.448 \\
\hline & (1.523) & $(1.611)$ & $(10.50)$ & $(2.117)$ & $(5.667)$ & $(2.549)$ \\
\hline \multirow[t]{2}{*}{ Constant } & & $0.725^{*}$ & & 2.992 & & $2.869^{*}$ \\
\hline & & $(0.380)$ & & $(1.824)$ & & (1.742) \\
\hline \multicolumn{7}{|c|}{ Speed of Adjustment } \\
\hline \multirow{2}{*}{ Model } & & $-0.449 * * *$ & & $-0.739 * * *$ & & $-0.594 * * *$ \\
\hline & & $(0.154)$ & & $(0.129)$ & & $(0.0703)$ \\
\hline
\end{tabular}

Note. Standard errors in parentheses. $* * * \mathrm{p}<0.01, * * \mathrm{p}<0.05, * \mathrm{p}<0.1$.

Source: Research Data (2016).

Table 3 indicates that the PMG estimates coefficient of political risk in the long run is 0.794 with a corresponding $\mathrm{p}$-value greater than the significance level of 0.05 and $\mathrm{t}$ statistic of 0.52 that is, $(0.794 / 1.53)=0.52$. In the short run, the coefficient is 2.201 with a corresponding p-value greater than the significance level of 0.05 and $\mathrm{t}$ statistic of 1.36 obtained as $(2.201 / 1.611)=1.36$. Therefore, the coefficients of political risk is not significant both in the short run and the long run. The results in Table 3 were further interpreted simultaneously with those of model 3.3 .

Table 4. Political risk as a moderator

\begin{tabular}{|c|c|c|c|c|c|c|}
\hline \multirow[b]{2}{*}{ VARIABLES } & \multicolumn{2}{|c|}{ PMG } & \multicolumn{2}{|c|}{ MG } & \multicolumn{2}{|c|}{ DFE } \\
\hline & Long run & Short Run & Long Run & Short Run & Long Run & Short RUN \\
\hline capital Expenditure & $\begin{array}{c}0.0161 \\
(0.0134)\end{array}$ & $\begin{array}{c}0.0286 \\
(0.0458)\end{array}$ & $\begin{array}{c}0.133 \\
(0.143)\end{array}$ & $\begin{array}{c}0.0549 \\
(0.0345)\end{array}$ & $\begin{array}{l}-0.0290 \\
(0.0342)\end{array}$ & $\begin{array}{c}0.0766^{* * * *} \\
(0.0236)\end{array}$ \\
\hline Political Risk & $\begin{array}{c}-6.964 * * * \\
(2.179) \\
\end{array}$ & $\begin{array}{l}5.171 * * \\
(2.069) \\
\end{array}$ & $\begin{array}{c}23.82 \\
(16.41) \\
\end{array}$ & $\begin{array}{l}-3.581 \\
(4.990) \\
\end{array}$ & $\begin{array}{c}5.352 \\
(7.080) \\
\end{array}$ & $\begin{array}{l}-0.0303 \\
(3.071) \\
\end{array}$ \\
\hline Capital Expenditure*Political Risk & $\begin{array}{c}-0.000383^{* * *} \\
(0.000119) \\
\end{array}$ & $\begin{array}{c}2.41 \mathrm{e}-05 \\
(0.000309) \\
\end{array}$ & $\begin{array}{l}-0.00364 \\
(0.00451) \\
\end{array}$ & $\begin{array}{l}-0.000765 \\
(0.000646) \\
\end{array}$ & $\begin{array}{l}-0.000406 \\
(0.000286)\end{array}$ & $\begin{array}{c}0.000100 \\
(0.000188)\end{array}$ \\
\hline Constant & & $\begin{array}{c}3.396 * * * \\
(1.297)\end{array}$ & & $\begin{array}{l}-11.93 \\
(10.54)\end{array}$ & & $\begin{array}{c}2.115 \\
(2.803)\end{array}$ \\
\hline \multicolumn{7}{|c|}{ SPEED OF ADJUSTMENT } \\
\hline Model & $\begin{array}{c}-0.501 * * * \\
(0.173)\end{array}$ & & $\begin{array}{c}-0.644 * * * \\
(0.233)\end{array}$ & & & D*** \\
\hline
\end{tabular}

Note. Standard errors in parentheses. *** $\mathrm{p}<0.01, * * \mathrm{p}<0.05$, * $\mathrm{p}<0.1$.

Source: Research Data (2016).

Table 4 above introduces political risk as a moderator and the coefficients of interest are those of the interaction terms. The PMG estimates show that coefficients of the interaction terms (capital expenditure and debt servicing) are significant in the long run whereas the interaction of current expenditure and political risk is insignificant in the long run. In Table 3, the coefficient of political risk is not significant in the long run. When these scenarios are compared to the decision-making criteria in Table 1 the null hypothesis (that political risk has no moderating effect on the relationship between government expenditure and Sectoral economic growth in Kenya) is subsequently rejected in the long run. Therefore, political risk has a moderating effect on the relationship between capital expenditure and Sectoral economic growth in Kenya. The sign (+ or -) of the interaction terms in the long run is contrary to that of coefficient of the variable for capital expenditures. Therefore, political risk reduces the effect of capital expenditures on Sectoral growth in the long run.

In the short run, the coefficients of interaction terms for capital expenditure in Table 4 are not significant. In Table 3, the coefficient of political risk is not significant. When these scenarios are compared to the 
decision-making criteria in Table 1, the null hypothesis (that political risk has no moderating effect on the relationship between government expenditure and Sectoral economic growth in Kenya) was supported at the significance level of 0.05 . Hence, in the short run political risk is neither an explanatory variable nor a moderator.

This is consistent with the findings of Cooray (2009) whose results indicate that both increased public spending and good governance can improve growth outcomes. Bruckner and Gradstein (2012) however concluded that higher income growth is significantly negatively correlated with countries' political risk. Political risk is neither an explanatory variable nor a moderator in the short run.

\section{Conclusion}

The test of hypothesis two indicates that capital expenditure has a significant effect on Sectoral economic growth in Kenya (both in the short run and in the long run) with a positive coefficient. This finding is supported by several studies and it contradicts some studies from other countries. This study therefore concludes that capital expenditure has both immediate and long term effect on Sectoral economic growth in Kenya. It further confirms that government investments in capital projects are growth boosters.

Finally, findings from test of hypothesis six indicate that political risk has a moderating effect on the relationship between capital expenditure and Sectoral economic growth in Kenya. It further indicates that political risk curbs the effect of capital expenditure in the long run. It is similarly concluded that political risk is neither an explanatory variable nor a moderator in the long run.

\section{Recommendations}

The National Treasury should increase allocations to capital expenditure budget as opposed to current expenditure because investments in infrastructure unlocks constraints to growth, including ongoing public investments in the railway network, modernizing seaports and airports, improving road networks and expanding energy and water supplies. Similarly, prioritization and budgetary allocation to capital projects should be based on the notion of efficient portfolios. In addition, budget officers should scrutinize past performance before allocating expenditure to various expenditure components. They should critically assess and evaluate whether value for money was achieved. The critical assessment involves a great sense of fiscal responsibility and good stewardship that take into account the greatest possible achievement of the country. This will eliminate wasteful spending and enhance prioritization of key projects.

The executive, judicial and legislative arms of government should enhance political stability and promote good governance to accelerate economic growth rate. This could be achieved through enhanced security, reduced levels of ethnic polarization, uphold the rule of law, ensuring government stability, enhanced government effectiveness, accountability and transparency. This will reduce the country's political risk which hinders economic growth if it is not well controlled.

\section{References}

Abdinasir, I. (2013). The effect of Public Expenditure on Economic Growth. In Proceedings of 1st Jomo Kenyatta University of Agriculture and Technology Reasearch Conference 12th and 13th September 2013 (pp. 1-11). Nairobi.

Alshahrani, S. A., \& Alsadiq, A. J. (2014). Economic Growth and Government Spending in Saudi Arabia: an Empirical Investigation. IMF Working Papers, 14. https://doi.org/10.5089/9781484348796.001

Brückner, M., \& Gradstein, M. (2012). Effects of Economic Growth on Political Risk: The Role of Ethnic Polarization Effects of Economic Growth on Political Risk (No. 285). Retrieved from www.carloalberto.org/research/working-papers

Cochrane, J. H. (2007). Portfolio Theory. Chicago: University of Chicago. Retrieved from http://faculty.chicagobooth.edu/john.cochrane/research/papers/portfolio_text.pdf

Cooray, A. (2009). Government Expenditure, Governance and Economic Growth. Comparative Economic Studies, 401-418. https://doi.org/10.1057/ces.2009.7

Dominick, M. (2002). A critical appraisal of the theories of government expenditure growth. Munich: GRIN Publishing GmbH.

Ekpung, E. G. (2014). Trend Analysis of Public Expenditure on Infrastructure and Economic Growth in Nigeria. International Journal of Asian Social Science, 4(4), 480-491.

Gangal, V. L. N., \& Gupta, M. H. (2013). Public Expenditure and Economic Growth: A Case Study of India. 
Global Journal of Management and Business Studies, 3(2), 191-196.

Khan, A. (2002). Budgets as Portfolios. In A. Khan, \& B. Hildreth (Eds.), Budget Theory in Public Sector.

Khan, A., \& Hildreth, W. B. (2002). Budget Theory in the Public. London: Greenwood Publishing Group. Retrieved from www.quorumbooks.com

Kosen, L., \& Muturi, W. (2013). Effects of Sectoral Budgetary Allocation on Economic Growth. In Proceedings of 1st Jomo Kenyatta University of Agriculture and Technology Reasearch Conference 12th and 13th September 2013 (pp. 100-111). Nairobi.

Kumo, W. L., Riel, J., \& Omilola, B. (2014). Afican economic Outlook-South Africa. Retrieved from http://www.africaneconomicoutlook.org

Lagat, K. K. (2015). Foreign Aid, Government Expenditure and Sectoral GDP Growth in Kenya. Kenyatta University. Retrieved from http://ir-library.ku.ac.ke/handle/123456789/14498

Loto, A. (2011). Impact of Government Sectoral Expenditure on Economic Growth. Journal of Economics and International $\quad$ Finance, $\quad 3(11), \quad$ Retrieved from http://www.iiste.org/Journals/index.php/JEDS/article/view/4128

Maingi, J. N. (2010). The Impact of Government Expenditure on Economic Growth in Kenya: 1963-2008. Kenyatta University.

Marnix, E. (2004). Portfolio Optimization: Beyond Markowitz. Retrieved from https://www.math.leidenuniv.nl/scripties/Engels.pdf

Martin, L. (1997). Outcome budgeting: A New Entrepreneurial Approach to Budgeting. Public Budgeting, Accounting and Financial Management. Retrieved from http://www.untag-smd.ac.id/files/Perpustakaan_Digital_1/BUDGET

Martins, P. (2011). Aid Absorption and Spending in Africa: A Panel Cointegration Approach. Journal of Development Studies, 47(12), 1925-1953. https://doi.org/10.1080/00220388.2011.579115

Muthui, J., Maingi, J., Gideon, K., Thuku, K., \& Kosimbei, G. (2013). The Impact of Public Expenditure Components on Economic Growth in Kenya 1964-2011. International Journal of Business and Social Sciences, 4(4), 233-254.

Njuguna, N. (2009). Government expenditure and economic growth in Kenya: An empirical analysis 1963-2006. Kenyatta Universty.

Nurudeen, A., \& Usman, A. (2010). Government Expenditure And Economic Growth in Nigeria, 1970-2008: A Disaggregated Analysis. Business and Economics Journal, 1-11.

Odhiambo, N. (2013). Government Expenditure and Economic Growth in South Africa: An Empirical Investigation. In Proceedings of 5th Annual American Business Research Conference 6-7 June, Sheraton LaGuardia East Hotel (p. 922069). New York.

Ojwang', K. (2013). Government Size and Economic Growth in Kenya. University of Nairobi.

Olopade, B., \& Olopade, D. (2010). The Impact of Government Expenditure on Economic Growth and Development in Developing Countries: Nigeria as a Case Study. Igbinedion University.

Onokaya, A. (2013). The impact of Public Capital Expenditure and Economic growth in Nigeria 2013. Global Journal of Economics and Finance, 2(1), 1-11. Retrieved from https://www.academia.edu/

Otieno, M. (2015). Total Debt Servicing and Macroeconomic Performance in Kenya. Kenyatta

Pesaran, M., Shin, Y., \& Smith, R. (2009). Pooled mean group estimation of dynamic heterogeneous panels. Journal of the American Statistical Association, (94), 289-326.

Ranjan, K., \& Sharma, C. (2008). Government Expenditure and Economic Growth:Evidence from India. The ICFAI University Journal of Public Finance, 6(3), 60-69. Retrieved from http://ssrn.com/

Republic of Kenya. (2007). Kenya Vision 2030-A Globally Competitive and Prosperous Kenya. Nairobi: Government Printer.

Republic of Kenya. (2010). Facts and Figure 2009. Nairobi. Retrieved from http://www.knbs.or.ke

Republic of Kenya. (2013). Vision 2030 Progress Report. Nairobi. Retrieved from http://www.vision2030.go.ke/wp-content/uploads/2015/06/Vision_2030-_score_booklet1.pdf 
Republic of Kenya. (2014). Social Protection, Culture and Recreation Sector MTEF 2012/13 - 2014/15 Sector Report. Nairobi.

Republic of Kenya. (2015a). Budget Policy Statement 2015. Nairobi. Retrieved from www.treasury.go.ke

Republic of Kenya. (2015b). Public Administration and International Relations MTEF Sector Report 2016/17-2018/19. Nairobi. Retrieved from www.treasury.go.ke

Romer, D. (1996). Advance Macro-Economics. New York: McGraw-Hill.

Rubin, I. (2007). Budget Theory and Budget Practice: How Good the Fit ? Public Administration Review, 50(2), 179-189. Retrieved from http://kisi.deu.edu.tr/yesim.kustepeli/3-irenerubin.pdf

Rutayisire, M. (2013). Threshold effects in the relationship between inflation and economic growth: Evidence from Rwanda. Retrieved from https://editorialexpress.com/cgi-bin/conference/

Statistics Times. (2015). Sector Wise Contribution to GDP India. Retrieved October 9, 2015, from http://statisticstimes.com/economy/Sectorwise-gdp-contribution-of-india.php

Taiwo, S., \& Agbatogun, K. (2011). Government Expenditure in Nigeria: A Sine Qua Non For Economic Growth and Development. Journal of Research in National Development, 9(2), 155-162.

Trochim, W. M. (2006). Research Methods Knowledge Base. Retrieved from http://www.socialresearchmethods.net/kb/design.php

UNDP. (2012). Sustainable Development in Kenya: Stocktaking in the run up to Rio +20 . Nairobi. Retrieved from http://statisticstimes.com/economy/Sectorwise-gdp-contribution-of-india.php

Wanjiku, M. R. (2013). Does Composition of Public Expenditure affect Economic growth ? Evidence from Kenya. The University of Nairobi. Retrieved from http://erepository.uonbi.ac.ke/bitstream/handle/

Westerlund, J. (2007). Testing for error correction in panel data. New York: Oxford University Press.

Whisman, \& McClelland. (2005). Designing, Testing and Interpreting Interactions and Moderator Effects in Family Research. Journal of Family Psychology, (19), 111-120. https://doi.org/10.1037/0893-3200.19.1.111

World Bank. (2011). United Republic of Tanzania Public Expenditure Review 2010. Retrieved from http://siteresources.worldbank.org/intanzania/Resources/Tanzania_PER_2010.pdf

World Bank. (2014). Kenya's Economy Continues to Grow in a Challenging Environment. Retrieved July 5, 2015 from http://www.worldbank.org/en/country/kenya/publication/kenya-economic-update

World Bank. (2015c). Kenya Among the Fastest Growing Economies in Africa. Retrieved from http://www.worldbank.org/en/news/press-release/2015/03/05/kenya-among-the-fastest-growing-economiesin-africa

Yahya, M., Hussin, M., \& Razak, A. (2012). Education Expenditure and Economic Growth : A Causal Analysis for Malaysia. Journal of Economic and Sustainable Development, 3(7), 71-82.

\section{Copyrights}

Copyright for this article is retained by the author(s), with first publication rights granted to the journal.

This is an open-access article distributed under the terms and conditions of the Creative Commons Attribution license (http://creativecommons.org/licenses/by/4.0/). 